\title{
FAKTOR-FAKTOR MOTIVASI KERJA PADA KARYAWAN LEMBAGA HUDA GROUP DI KECAMATAN TAMANSARI KABUPATEN BOGOR
}

\author{
Irfan Bahar Nurdin \\ STAI Al Hidayah Bogor \\ pena.irfan@gmail.com
}

\section{ABSTRACT}

This study aims to determine the factors-factors that became the source of motivation to work on the employees of institutions Huda Group in Tamansari, Bogor. The hypothesis of this research is monotheism and jihad factor, leadership, communication, requirement, training, compensation and achievement that significantly influence to become the source of motivation factor of Huda Institute Group employee. Sampling method using saturated sample (census) to all employees with the number of respondents is 80 people and all are employees of Huda Group Bogor. All respondents were given a questionnaire related to employee motivation factor analysis. The results show that monotheism and jihad, leadership, communication, requirements, training, compensation, and achievement of significant influence 0,000. source of motivational factors. The achievement factor, achieving the highest score compared with other variables that is 0.873 or $87.3 \%$ indicates that the motivation relationship is very strong on motivation, monotheism and jihad factor reaching value 0,594 or $59,4 \%$ have strong relation with motivation but lower. rather than more variables. The leadership factor reaches 0.771 or $77.1 \%$ (very strong), the communication factor reaches 0.686 or $68,6,1 \%$ (strong), the need factor reaches 0.846 or $84.6 \%$ (very strong), the training factor reaches the value of 0.669 or $66.9 \%$ indicates that a strong relationship, a compensation factor of 0.788 or $78.8 \%$ indicates that the relationship is very strong against the motivation of Huda Group employees. Huda Group must increase attention so as to maintain the already very strong factor, and increase the motivation factor, especially monotheism and jihad in a more appropriate way to be the main motivation and perfect, so that employees do work is driven by the motivation to worship and work with the spirit of jihad.

\section{ABSTRAK}

Penelitian ini bertujuan untuk mengetahui faktor- faktor yang menjadi sumber motivasi untuk bekerja pada pegawai institusi Huda Group di Tamansari, Bogor. Hipotesis dari penelitian ini adalah faktor monoteisme dan jihad, kepemimpinan, komunikasi, persyaratan, pelatihan, kompensasi dan prestasi yang signifikan berpengaruh menjadi sumber faktor motivasi karyawan pada Lembaga Huda Grup. Metode pengambilan sampel dengan menggunakan sampel jenuh (sensus) kepada seluruh karyawan dengan jumlah responden adalah 80 orang dan semuanya karyawan tetap Huda Group Bogor. Semua responden diberi kuesioner yang berkaitan dengan analisis faktor motivasi karyawan. Hasil penelitian menunjukkan bahwa monoteisme dan jihad, kepemimpinan, komunikasi, persyaratan, pelatihan, kompensasi, dan pencapaian pengaruh signifikan 0,000. Sumber faktor motivasi. Faktor 
prestasi, mencapai nilai tertinggi dibandingkan dengan variabel lain yaitu 0,873 atau $87,3 \%$ menunjukkan bahwa hubungan motivasi sangat kuat pada motivasi, faktor monoteisme dan jihad mencapai nilai 0,594 atau 59,4\% memiliki hubungan yang kuat dengan motivasi namun lebih rendah. daripada variabelnya lebih banyak. Faktor kepemimpinan mencapai nilai 0,771 atau $77,1 \%$ (sangat kuat), faktor komunikasi mencapai nilai 0,686 atau 68,6,1\% (kuat), Faktor Kebutuhan mencapai 0,846 atau 84,6\% (sangat kuat), faktor pelatihannya mencapai nilai 0,669 atau $66,9 \%$ menunjukkan bahwa hubungan yang kuat, faktor kompensasi mencapai nilai 0,788 atau 78,8\% menunjukkan bahwa hubungan tersebut sangat kuat terhadap motivasi karyawan Huda Group. Lembaga Huda Group harus meningkatkan perhatian sehingga bisa mempertahankan faktor yang sudah sangat kuat, dan meningkatkan faktor motivasinya, terutama monoteisme dan jihad dengan cara yang lebih tepat untuk bisa menjadi motivasi utama dan sempurna, sehingga karyawan melakukan kerja keras didorong oleh motivasi beribadah dan bekerja dengan semangat jihad.

KataKunci : Kepemimpinan, komunikasi, motivasi.

\section{PENDAHULUAN}

Manusia sebagai pusat kegiatan baik itu dalam masyarakat luas maupun organisasi atau perusahaan dan khususnya di dalam organisasi merupakan sumber daya yang sangat menentukan untuk berjalannya organisasi dibandingkan dengan mesin atau perangkat apapun yang ada di dalamnya (Masyhudulhak, 2001:2).

Peningkatan kualitas SDM daerah untuk meningkatkan kinerja melalui motivasi kerja yang baik dengan menyelenggarakan diklat sesuai standar kompetensi tenaga kerja ASEAN, penciptaan iklim ketenagakerjaan daerah yang lebih kondusif dengan meninjau ulang pengaturan upah minimum provinsi/kabupaten/kota, dan melakukan sinergi serta sinkronisasi antara strategi dan program pemerintah dengan strategi dan program swasta dalam mencermati dan memanfaatkan peluang pasar ASEAN (Jurnal Economica, Vol. I No. 1 Januari 2015 hal. 26).

Kesuksesan sebuah organisasi itu bergantung kepada sumber daya manusia yang berkualitas dan memiliki motivasi yang kuat dalam melakukan pekerjaanya.Islam mengajarkan bekerja bukan sekedar mencari harta tanpa tujuan, namun bekerja adalah sebuah implementasi ibadah kepada Allah (S.W.T) secara luas (lihat Jurnal Edukasi Islam, Vol. 4 No.07. hal. 787-805). Maka peranan motivasi yang paling tinggi dalam mewujudkan etos kerja bagi 
seorang muslim adalah ibadah dengan mentauhidkan Allah (S.W.T). Sebagaimana dalam firman Allah (S.W.T):

"Dan tidaklah Aku ciptakan jin dan manusia, kecuali untuk beribadah kepadaku" (mentauhidkan-Ku) Q.S. Adz-Dzariyat [56]: 61. Maka tauhid merupakan landasan utama dalam motivasi sumber daya manusia yang asasi dalam segala sendi kehidupanya termasuk dalam mewujudkan etos kerja seorang muslim (lihat Jurnal Edukasi Islam,Vol. 3 No.05. hal. 520-532).

Lembaga Huda Group yang berkedudukan di Bogor merupakan Lembaga Nirlaba (NGO) konsorsium dari lima yayasan yaitu Yayasan Cinta Remaja Bangsa, Yayasan Takrimul Qur'an, Yayasan Mutiara Surga, Yayasan Nuurul Ummah Nusantara dan Yayasan Huda Cendekia. Peranananya sangat penting dalam melakukan kegiatan-kegiatan sosial, pendidikan dan dakwah yang telah di programkan secara kontinyu dan berkala.Sebagai lembaga non profit harus melaksanakan kegiatan-kegiatan tersebut mengandalkan dari biaya sumbangan para donatur berupa zakat, infak, dan sedekah baik pribadi atau komunitas khususnya yang sudah menjadi jaringan dakwah.

Berdasarkan laporan kinerja Lembaga Huda Group tahun 2014 s.d 2015 mengalami kejenuhan bahkan menurun, baik pengumpulan dana sumbangan atau ide pengembangan SDM dan program yang mempengaruhi terhadap motivasi karyawan. Oleh karena itu, penulis melihat perlunya melakukan penelitian faktor-faktor motivasi yang menjadi dasar utama pendorong dari kinerja Lembaga Huda Group khususnya.

Dari uraian di atas maka dalam analisis yang akan dilakukan dirumuskan sebagai berikut; 1) Bagaimana faktor tauhid dan jihad menjadi sumber motivasi karyawan lembaga Huda Group?, 2) Bagaimana faktor kepemimpinan menjadi sumber motivasi karyawan lembaga Huda Group?, 3) Bagaimana faktor komunikasi menjadi motivasi karyawan lembaga Huda Group?, 4) Bagaimana kebutuhan manusia sebagai menjadi motivasi karyawan lembaga Huda Group?, 5) Bagaimana faktor pelatihan menjadi motivasi karyawan lembaga Huda Group?, 6) Bagaimana faktor konpensasi menjadi sumber motivasi karyawan lembaga Huda Group?, dan7) Bagaimana Analisis faktor prestasi menjadi sumber motivasi karyawan lembaga Huda Group? 
Tujuan penelitian ini untuk menganalisis faktor-faktor yang menjadi sumber motivasi pada karyawan Lembaga Huda Group di Tamansari Bogor, baik pada yang bersifat khusus maupun faktor-faktor umum.

\section{TINJAUAN TEORITIS}

Dalam penelitian terdahulu, Ni Made Nurcahyani, dan I.G.A. Dewi Adnyani (2016) dalam jurnal Penelitian diketahui pengaruh kompensasi, motivasi, kompensasi terhadap kinerja karyawan, motivasi terhadap kienrja karyawan dan untuk mengetahui pengaruh kepuasan kerja terhadap kinerja karyawan pada PT. Sinar Sosro Pabrik Bali.Penelitian ini menggunakan sampel jenuh dengan menggunakan seluruh karyawan pada PT. Sinar Sosro Pabrik Bali.Metode analisis dari penelitian ini menggunakan analysis jalur (Path Analysis).Berdasarkan hasil analisis ditemukan bahwa kompensasi berpengaruh positif terhadap kepuasan kerja, motivasi berpengaruh positif dan signifikan terhadap kepuasan kerja, kompensasi berpengaruh positif dan signifikan terhadap kinerja karyawan, motivasi berpengaruh positif dan signifikan terhadap kinerja karyawan, kepuasan kerja berpengaruh positif dan signifikan terhadap kinerja karyawan dan kepuasan kerja memediasi pengaruh kompensasi dan motivasi terhadap kinerja karyawan. Berdasarkan hasil penelitian, perusahaan PT. Sinar Sosro Pabrik Bali sebaiknya memberikan kompensasi secara adil, memotivasi karyawan dengan promosi jabatan.

Enggar Dwi Jatmiko, Bambang Swasto, dan Gunawan Eko N (2015) dalam jurnalnya, dalam penelitiannya menjelaskan pengaruh motivasi kerja dan komitmen organisasional terhadap kinerja karyawan pada karyawan kompartemen pabrik II PT. Petrokimia Gresik. Jenis penelitian yang digunakan adalah penelitian survei yang bersifat penjelasan (explanatory research).Jumlah sampel pada penelitian ini sebanyak 89 karyawan.Dari hasil analisis statististik bahwa variabel motivasi kerja berpengaruh signifikan terhadap variabel kinerja karayawan, dan variabel komitmen organisasional berpengaruh signifikan terhadap variabel kinerja karyawan, serta variabel motivasi kerja dan variabel komitmen organisasional berpengaruh signifikan terhadap variabel kinerja karyawan. 
Sindi Larasati (2014) dalam jurnalnya menjelaskan, berdasarkan hasil kuesioner dengan 180 orang responden,penilaian karyawan Wilayah Telkom Jabar Barat Utara (Witel Bekasi)terhadap motivasi kerja dan kinerja termasuk dalam kategori sangat tinggi. Pada hasil pengujian hipotesis dapat disimpulkan bahwa variabel Motivasi Kerja $(X)$ yang terdiri dari Kebutuhan Prestasi (X1), Kebutuhan Afiliasi (X2) dan Kebutuhan Kekuasaan (X3) secara simultan dan parsial berpengaruh signifikan terhadap Kinerja Karyawan (Y).Pada hasil uji koefisien determinasi (R2) diperoleh nilai sebesar 0.551. Hal ini berarti bahwa besarnya pengaruh motivasi kerja terhadap kinerja karyawan adalah sebesar $55.1 \%$, sedangkan sisanya $44.9 \%$ dipengaruhi faktor-faktor lain yang tidakditeliti dalam penelitian ini.

\section{Motivasi}

Secara bahasa motivasi berasal dari kata motif yang berarti "dorongan" atau rangsangan atau "daya penggerak" yang ada dalam diri seseorang.Dalam kamus Bahasa Indonesia diartikan: Sebab-sebab yang menjadi dorongan tindakan seseorang; dasar pikiran dan pendapat; suatu yang menjadi pokok. Motivasi adalah suatu dorongan kehendak yang menyebabkan seseorang melakukan suatu perbuatan untuk mencapai tujuan tertentu.

Motivasi adalah suatu yang pokok, yang menjadi dorongan seseorang untuk bekerja, secara sederhana, motivasi adalah menciptakan semangat gairah kerja (Ishak Arep, 2004). Arti motivasi adalah alasan yang mendasari sebuah perbuatan yang dilakukan oleh seorang, alasan yang sangat kuat untuk mencapai apa yang diinginkannya dengan mengerjakan pekerjaannya yang sekarang (Hendri Tanjung, 2004).

Motivasi lebih dominan berasal dari kemampuan diri dalam membangkitkan potensi diri yang selanjutnya dikenal dengan self management. Dalam Islam sumber motivasi itu bersumber dari hati dimana seseorang mengetahui bagaimana dia harus mendekatkan diri kepada Allah (S.W.T) baik dalam ibadah mahdhah (ritual) ataupun dalam bekerja. Hati merupakan faktor penentu yang membuat manusia menjadi termotivasi baik atau buruknya tergantung kepada kondisi hati seseorang. 
Rasulallah (SAW) bersabda: "Ingatlah, sesungguhnya dalam jasad manusia itu ada segumpal daging, jika ia baik, baiklah seluruh jasad, dan jika ia rusak, rusaklah seluruh jasad, segumpal daging itu adalah hati (nurani)." (HR. Al Bukhari dan Muslim).

Bahkan seluruh pekerjaan akan berkualitas dan produkktif jika memiliki motivasi niat yang tulus. Dari Umar (Ra) bahwa Rasulullah (SAW) bersabda, "Amal itu tergantung niatnya, dan seseorang hanya mendapatkan sesuai niatnya.Barang siapa yang hijrahnya kepada Allah SWT dan RasulNya, maka hijrahnya kepada Allah SWT dan Rasul-Nya, dan barang siapa yang hijrahnya karena dunia atau karena wanita yang hendak dinikahinya, maka hijrahnya itu sesuai ke mana ia hijrah." (H.R. Al Bukhari, Muslim, dan empat imam Ahli Hadits).

Jika hati termotivasi dengan niat yang baik maka otomatis akan meingkatkan gairah kerja seseorang, akibatnya seluruh pekerjaan seberat apapun akan dirasakan ringan sehingga produktivitasnya meningkat (Tanjung, 2004).

Motivasi menjadi suatu kekuatan, tenaga atau daya, atau suatu keadaan yang kompleks dan kesiapsediaan dalam diri individu untuk bergerak ke arah tujuan tertentu, baik disadari maupun tidak disadari (Makmun, 2003).Motivasi seseorang dapat ditimbulkan dan tumbuh berkembang melalui dirinya sendiri-intrinsik dan dari lingkungan-ekstrinsik (Elliot et al., 2000; Sue Howard, 1999). Motivasi intrinsik bermakna sebagai keinginan dari diri sendiri untuk bertindak tanpa adanya rangsangan dari luar (Elliott, 2000). Motivasi intrinsik akan lebih menguntungkan dan memberikan keajegan dalam belajar. Motivasi ekstrinsik dijabarkan sebagai motivasi yang datang dari luar individu dan tidak dapat dikendalikan oleh individu tersebut (Sue Howard, 1999). Elliott et. al. (2000), mencontohkannya dengan nilai, hadiah, dan/atau penghargaan yang digunakan untuk merangsang motivasi seseorang.

\section{Teori Model Motivasi}

Teori-teori motivasi berikut ini berbagai teori motivasi menurut para pakarnya yaitu: Maslow (teori hierarki kebutuhan), McClelland (teori motivasi 
prestasi), Mc Gregor (teori X dan Y), teori motivasi Hezberg, dan Teori ERG Aldefer. Berikut penjelasannya:

\section{Teori Motivasi Maslow}

Teori Maslow Maslow dalam Reksohadiprojo dan Handoko (1996), membagi kebutuhan manusia sebagai berikut: Kebutuhan Fisiologis, kebutuhan rasa aman, kebutuhan sosial, kebutuhan penghargaan, dan Kebutuhan Aktualisasi diri.

Teori Maslow mengasumsikan bahwa orang berkuasa memenuhi kebutuhan yang lebih pokok (fisiologis) sebelum mengarahkan perilaku memenuhi kebutuhan yang lebih tinggi (perwujudan diri). Kebutuhan yang lebih rendah harus dipenuhi terlebih dahulu sebelum kebutuhan yang lebih tinggi seperti perwujudan diri mulai mengembalikan perilaku seseorang. Hal yang penting dalam pemikiran Maslow ini bahwa kebutuhan yang telah dipenuhi memberi motivasi. Apabila seseorang memutuskan bahwa ia menerima uang yang cukup untuk pekerjaan dari organisasi tempat ia bekerja, maka uang tidak mempunyai daya intensitasnya lagi.

Jadi bila suatu kebutuhan mencapai puncaknya, kebutuhan itu akan berhenti menjadi motivasi utama dari perilaku. Kemudian kebutuhan kedua mendominasi, tetapi walaupun kebutuhan telah terpuaskan, kebutuhan itu masih mempengaruhi perilaku hanya intensitasnya yang lebih kecil.

\section{Teori Motivasi Prestasi dari Mc. Clelland}

Konsep penting lain dari teori motivasi yang didasarkan dari kekuatan yang ada pada diri manusia adalah motivasi prestasi menurut Mc Clelland seseorang dianggap mempunyai apabila dia mempunyai keinginan berprestasi lebih baik daripada yang lain pada banyak situasi Mc. Clelland menguatkan pada tiga kebutuhan menurut Reksohadiprojo dan Handoko (1996: 85) yaitu; 1) Kebutuhan prestasi tercermin dari keinginan mengambil tugas yang dapat dipertanggung jawabkan secara pribadi atas perbuatanperbuatannya, 2) Kebutuhan afiliasi, kebutuhan ini ditujukan dengan adanya bersahabat, 3) Kebutuhan kekuasaan, kebutuhan ini tercermin pada seseorang yang ingin mempunyai pengaruh atas orang lain, dia peka terhadap struktur pengaruh antar pribadi dan ia mencoba menguasai orang 
lain dengan mengatur perilakunya dan membuat orang lain terkesan kepadanya, serta selalu menjaga reputasi dan kedudukannya.

\section{Teori X dan Y dari Mc. Gregor}

Teori motivasi yang menggabungkan teori internal dan teori eksternal yang dikembangkan oleh Mc. Gregor.la telah merumuskan dua perbedaan dasar mengenai perilaku manusia. Kedua teori tersebut disebut teori $\mathbf{X}$ dan Y. Teori tradisional mengenai kehidupan organisasi banyak diarahkan dan dikendalikan atas dasar teori X. Adapun anggapan yang mendasari teoriteori X menurut Reksohadiprojo dan Handoko (1996: 87) sebagai berikut.

Rata-rata pekerja itu malas, tidak suka bekerja dan kalau bisa akan menghidarinya. Karena pada dasarnya tidak suka bekerja maka harus dipaksa dan dikendalikan, diperlakukan dengan hukuman dan diarahkan untuk pencapaian tujuan organisasi.Rata-rata pekerja lebih senang dibimbing, berusaha menghindari tanggung jawab, mempunyai ambisi kecil, kemamuan dirinya diatas segalanya.

Teori ini masih banyak digunakan oleh organisasi karena para manajer bahwa anggapan-anggapan itu benar dan banyak sifat-sifat yang diamati perilaku manusia, sesuai dengan anggapan tersebut teori ini tidak dapat menjawab seluruh pertanyaan yang terjadi pada orgaisasi. Oleh karena itu, Mc. Gregor menjawab dengan teori yang berdasarkan pada kenyataannya.

\section{Faktor-Faktor Motivasi}

Tanjung (2004) menyebutkan faktor-faktor motivasi pada SDM dalam perusahaan swasta atau pemerintahan dan BMUN disimpulkan dalam enam faktor dan menambahkan faktor rohani (agama) dalam Islam yaitu faktor tauhid dan jihad, faktor-faktor itu antara lain:

Faktor Tauhid dan Jihad. Faktor ini mencakup ibadah, muamalah dan kemampuan. Seorang muslim melakukan amal perbuatanya harus dilandasi dengan tauhid karena itu merupakan tuntutan syahadah wujud dari ibadah kepada Allah (S.W.T), “"Dan Aku tidak menciptakan jin dan manusia melainkan supaya mereka beribadah kepada-Ku.” (Q.S. Adz Dzariyat: 56) 
Dan manusia berjanji bahwa ibadahnya, hidup dan matinya hanya untuk mentauhidkan Allah S.W.T Ta'ala.

"Sesungguhnya shalatku, ibadahku, hidupku dan matiku hanyalah untuk Allah SWT, Tuhan seluruh alam, tidak ada sekutu bagi-Nya; dan demikianlah yang diperintahkan kepadaku dan aku adalah orang yang pertama-tama berserah diri (muslim)." (Q.S Al An'aam [6] 162-163)

Dalam melaksanakan suatu amal dan perbuatan atau pekerjaan maka harusdilakukan dengan semangat jihad penuh kesungguhan, Allah S.W.T memberikan motivasi dalam firman-Nya, "Dan orang-orang yang bersungguh-sungguh di jalan Kami niscaya akan Kami tunjukkan kepada mereka jalan-jalan [menuju keridhaan] Kami. Dan sesungguhnya Allah SWT akan bersama dengan orang-orang yang berbuat ihsan.” (Q.S. Al-'Ankabut [29]: 69).

\section{Faktor Kepemimpinan}

Mencakup gaya kepemimpinan dan supervisi. Kepemimpinan adalah kemampuan seseorang untuk menguasai atau mempengaruhi orang lain atau masyarakat yang berbeda-beda menuju pencapaian tertentu.

Dalam mencapai tujuan pemimpin dapat menguasai dan mempengaruhi serta memotivasi orang lain. Menurut Gillies (1996), gaya kepemimpinan berdasarkan wewenang dan kekuasaan dibedakan menjadi empat yaitu: otoriter demokratis (Democratic Leadership), partisipatif, bebas (Free Rein Leadership). Oleh karena itu, kemampuan memimpin dalam memotivasi bawahan tergantung kepada jiwa kepemimpinanya, artinya tergantung kepada sikap dan penampilan dalam memimpin berlandaskan pada pokok-pokok kepemimpinan.

\section{Faktor Komunikasi}

Mencakup hubungan antara manusia, baik hubungan atasanbawahan, hubungan sesama atasan dan hubungan sesame bawahan. Komunikasi yang lancar adalah komunikasi terbuka dimana informasi mengalir bebas dari atas ke bawah atau sebaliknya. Dalam seluruh organisasi, umpan balik dapat diutarakan dalam suasana saling percaya, orang saling tertarik, saling memperhatikan dan saling menghormati. 
Terdapat 5 kunci komunikasi lancar dalam organisasi, yaitu: 1) terbuka, 2) umpan balik, 3) saling percaya, 4) saling meperhatikan, dan 5) saling menghormati.

Untuk melakukan komunikasi yang lancar maka diperlukan media yang efektif dalam komunikasi. Di era digital sekarang, seluruh informasi dapat diakses dengan berbagai cara, baik melalui email, sosmed, telpon, sms, dan media langsung dialog sesuai kondisi yang efektif dalam melakukan komunikasi.

Komunikasi yang lancar akan membangun motivasi yang baik terhadap karyawan karena tumbuhnya saling percaya, saling menghormati dan saling menghargai menjadi budaya organisasi yang akan membangun semangat berkerja dalam organisasi tersebut.

\section{Faktor Kebutuhan}

Ada tiga kebutuhan manusia mencakup kebutuhan dasar (ekonomis), kebutuhan rasa aman (psikologis) dan kebutuhan sosial, kebutuhan ekonomis, kebutuhan psikologis, kinerja, tinggi rendahnya kepuasan karyawan, dan kebutuhan sosial, Seseorang dengan menduduki jabatan akan merasa dirinya dipercayai, diberi tanggung jawab, dan wewenang yang lebih besar untuk melakukan kegiatan-kegiatannya.

\section{Faktor Pelatihan}

Mencakup pelatihan dan pengembangan serta kebijakan manajemen dalam mengembangkan karyawan. Seorang pegawai yang mempunyai tingkat pendidikan yang lebih tinggi biasanya akan lebih termotivasi karena sudah mempunyai wawasan yang lebih luas dibandingkan dengan karyawan yang lebih rendah tingkat pendidikannya, demikian juga sebaliknya jika tingkat pendidikan yang dimilikinya tidak digunakan secara maksimal ataupun tidak dihargai sebagaimana layaknya oleh manajer maka hal ini akan membuat karyawan tersebut mempunyai motivasi yang rendah di dalam bekerja, terlebih jika di sebuah organisasi dikembangkan dengan adanya pelatihan-pelatihan untuk mengasah skill dari dasar pendidikan yang mereka miliki. 


\section{Faktor Kompensasi}

Mencakup: upah, gaji, imbalan/balas jasa, kebijakan manajemen dan aturan administrasi penggajian. Pengakuan pihak manajemen terhadap karyawan. Hendi Tanjung (2004) mengatakan bahwa salah satu tantangan utama perusahaan dalam manajemen sumber daya manusianya adalah mengembangkan sistem kompensasi yang dapat memotivasi orang.

Kompensasi yang memadai merupakan alat motivasi yang paling ampuh bagi perusahaan untuk memberikan dorongan kepada para karyawan untuk bekerja secara baik. Menurut Mathis dan Jackson (2006), penghargaan nyata yang diterima karyawan karena bekerja adalah dalam bentuk gaji, insentif, dan tunjangan. Satu hal yang penting terhadap retensi karyawan adalah mempunyai "kompensasi kompetitif" artinya harus dekat dengan apa yang diberikan oleh perusahaan yang lain dan apa yang diyakini oleh karyawan sesuai dengan kapabilitas, pengalaman dan kinerjanya, apabila tidak dekat perputaran akan lebih tinggi.

Masalah pemberian kompensasi kepada karyawan, diantaranya; 1) Arti gaji bagi karyawan, 2) Dasar pemberian gaji, 3) Besarnya gaji, 4) Cara pemberian gaji dan, 5) Kompensasi selain upah dan gaji, berupa makan siang bersama pejabat perusahaan/organisasi, ucapan terima kasih kepada keluarga karyawan yang berprestasi, memberikan hadiah, menyediakan tempat parkir untuk supervisor dan lain-lainya.

\section{Faktor Prestasi}

Mencakup prestasi dan kondisi serta lingkungan kerja yang mendorong prestasi kerja tersebut.Membahas mengenai motivasi kerja, tidak dapat terlepas dari pembahasan mengenai prestasi kerja.Karena motivasi kerja merupakan bagian yang terpenting dari tingkah laku kerja tersebut. Prestasi kerja dapat diartikan sebagai hasil yang dicapai seseorang menurut ukuran yang berlaku untuk pekerjaan yang bersangkutan.

Menurut Hasibuan (1995:105), prestasi kerja adalah suatu hasil kerja yang dicapai seseorang dalam melaksanakan tugas-tugas yang dibebankan kepadanya yang didasarkan atas kecakapan, pengalaman dan kesungguhan serta waktu. 
Penilaian prestasi kerja adalah proses melalui mana organisasiorganisasi mengevaluasi atau menilai prestasi kerja Menurut Heidrahman dan Suad Husnan (1990:126), faktor-faktor prestasi kerja yang perlu dinilai adalah sebagai berikut: kuantitas kerja, kualitas kerja, keandalan, inisiatif, kerajinan.

Program-program perusahaan dapat memberikan penghargaan untuk karyawan yang berprestasi dan tim kerja, berupa penghargaan bulanan, bonus makan malam, atau penghargaan tahunan dan lain-lain.

Dari telaah pustaka di atas, maka disusun suatu kerangka pemikiran teoritis yang menyatakan bahwa faktor tauhid dan jihad, kepemimpinan, komunikasi, kebutuhan, konpensasi, pelatihan dan prestasi menjadi sumber motivasi karyawaanyang akan diurai dalam variabel penelitian ini, untuk lebih jelasnya kerangka pemikiran teoritis dan model penelitian digambarkan dalam gambar berikut:

\section{Gambar 1.}

\section{Gambar Kerangka Pemikiran}

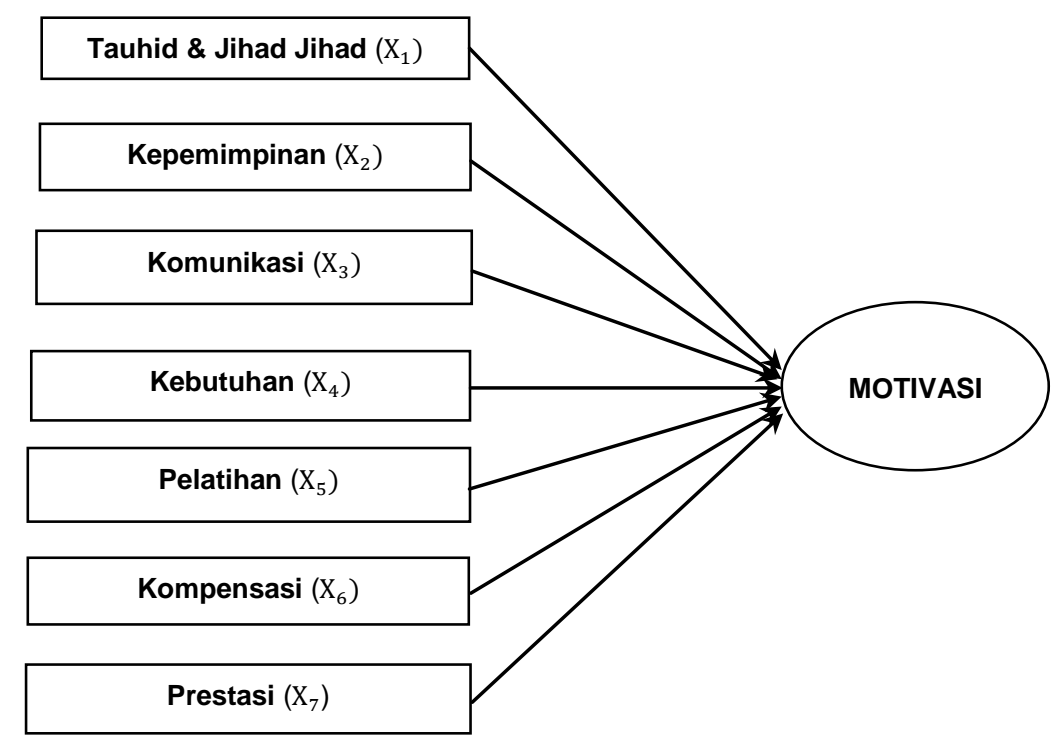

Hipotesis adalah jawaban sementara dari rumusan masalah atau pertanyaan penelitian (Nursalam, 2008). Sedangkan menurut Notoatmodjo (2010) hipotesis adalah jawaban sementara dari suatu penelitian, patokan duga, atau dalil sementara, yang kebenarannya akan dibuktikan dalam penelitian tersebut. Setelah melalui pembuktian dari hasil penelitian. Maka hipotesis dapat benar atau salah, dapat diterima atau ditolak. 
Berdasarkan masalah yang dijelaskan, maka hipotesis yang diajukan dalam penelitian ini adalahsebagai berikut:

$\mathrm{H} 1$ : Ada hubungan antara faktor tauhid dan jihad dengan motivasi karyawan.

$\mathrm{H} 2$ : Ada hubungan antara faktor kepemimpinandengan motivasi karyawan.

H3 : Ada hubungan antara faktor komunikasi dengan motivasi karyawan.

H4 : Ada hubungan antara faktor kebutuhan dengan motivasi karyawan.

H5 : Ada hubungan antara faktor pelatihan dengan motivasi karyawan.

H6 : Ada hubungan antara faktor kompensasidengan motivasi karyawan.

$\mathrm{H} 7$ : Ada hubungan antara faktor prestasidengan motivasi karyawan.

\section{METODE PENELITIAN}

Penelitian ini menggunakan pendekatan penelitian kuantitatif, Penelitian ini dilakukan pada Lembaga Huda Group Jln. Kapten Yusuf No. 60 RT03/01.Sukamantri Tamansari Bogor mulai bulan Januari sampai dengan bulan Maret 2016.

Populasi dalam penelitian ini adalah karyawan Huda Group sebanyak 80 orang. Metode pengambilan sampel dalam penelitian ini menggunakan sampling jenuh (sensus). Menurut Sugiyono (2008:115) sampling jenuh adalah teknik pengambilan sampel bila semua anggota populasi digunakan sebagai sampel karena jumlah populasinya kecil.

Tabel 1

Operasional Penelitian

\begin{tabular}{|c|c|c|c|}
\hline Variabel & Definisi & Indikator & Pengukuran \\
\hline $\begin{array}{l}\text { Tauhid dan } \\
\text { jihad } \\
\left(\mathrm{X}_{1}\right)\end{array}$ & $\begin{array}{l}\text { Karyawan memiliki } \\
\text { motivasi kerja ibadah } \\
\text { kepada Allah SWT yang } \\
\text { menciptakan, memiliki, } \\
\text { memelihara dan } \\
\text { melindungi. Dan } \\
\text { melakukan pekerjaan } \\
\text { dengan penuh } \\
\text { kesungguhan }\end{array}$ & $\begin{array}{l}\text { 1. Merasa bekerja adalah } \\
\text { ibadah } \\
\text { 2. Yang menjamin rezeki } \\
\text { adalah Allah SWT } \\
\text { 3. Berkerja dengan ikhtiar yg } \\
\text { maksimal dan tawakkal } \\
\text { 4. Melakukan pekerjaan } \\
\text { dengan smangat juang }\end{array}$ & Skala Likert \\
\hline $\begin{array}{l}\text { Kepemimpi } \\
\text { nan } \\
\left(\mathrm{X}_{2}\right)\end{array}$ & $\begin{array}{l}\text { Gaya kepemimpinan } \\
\text { dalam memberikan } \\
\text { motivasi kepada }\end{array}$ & $\begin{array}{l}\text { 1. Memiliki pengetahuan cukup } \\
\text { tentang teksnis pekerjaan } \\
\text { 2. Memahami garis-garis besar }\end{array}$ & Skala Likert \\
\hline
\end{tabular}




\begin{tabular}{|c|c|c|c|}
\hline & karyawan & $\begin{array}{l}\text { kebijaksanaa organisasi } \\
\text { 3. Setia dan memegang teguh } \\
\text { setiap ucapanya } \\
\text { 4. Memberikan penilaian yang } \\
\text { baik kepada karyawan }\end{array}$ & \\
\hline $\begin{array}{l}\text { Komunikas } \\
\text { i } \\
\left(\mathrm{X}_{3}\right)\end{array}$ & $\begin{array}{l}\text { Komunikasi antara } \\
\text { pimpinan dengan } \\
\text { bawahan memiliki } \\
\text { komunikasi yang lancar, } \\
\text { sehingga karyawan } \\
\text { termotivasi dalam bekerja }\end{array}$ & $\begin{array}{l}\text { 1. Komunikasi lancar, perintah } \\
\text { jelas mudah dipahami dan } \\
\text { bisa dilaksanakan } \\
\text { 2. Adanya saling menghormati, } \\
\text { saling percaya dan } \\
\text { keterbukaan }\end{array}$ & Skala Likert \\
\hline $\begin{array}{l}\text { Kebutuhan } \\
\left(\mathrm{X}_{4}\right)\end{array}$ & $\begin{array}{l}\text { Terpenuhinya kebutuhan } \\
\text { dasar dengn halal, baik } \\
\text { kebutuhan ekonomis, } \\
\text { psikologis dan sosial } \\
\text { sehingga termotivasi } \\
\text { untuk bekerja keras. }\end{array}$ & $\begin{array}{l}\text { 1. Secara ekonomis } \\
\text { terpenuhinya kebutuhan } \\
\text { pokok } \\
\text { 2. Merasa dihargai } \\
\text { pekerjaanuya } \\
\text { 3. Secara sosial karyawan } \\
\text { memiliki banyak mitra }\end{array}$ & Skala Likert \\
\hline $\begin{array}{l}\text { Pelatihan } \\
\left(\mathrm{X}_{5}\right)\end{array}$ & $\begin{array}{l}\text { Karyawan mendapatkan } \\
\text { pelatihan dalam } \\
\text { meningkatkan knowledge, } \\
\text { skill, attitude untuk } \\
\text { meningkatkan kualitas } \\
\text { SDM }\end{array}$ & $\begin{array}{l}\text { 1. Keahlian dan kemapuanya } \\
\text { meningkat } \\
\text { 2. Melakukan pekerjaan } \\
\text { dengan professional } \\
\text { 3. Semangat melakukan } \\
\text { inovasi dalam pekerjaan }\end{array}$ & Skala Likert \\
\hline $\begin{array}{l}\text { Kompnsasi } \\
\left(\mathrm{X}_{6}\right)\end{array}$ & $\begin{array}{l}\text { System konpensasi yang } \\
\text { diberikan kepada } \\
\text { karyawan sesuai dengan } \\
\text { tingkat tanggung jawab, } \\
\text { hasil kerja dan kebutuhan }\end{array}$ & $\begin{array}{l}\text { 1. Insentif yang diperoleh } \\
\text { sesuai dengan beban kerja } \\
\text { 2. Mencukupi kebutuhan pokok } \\
\text { 3. Mendapatkan penghargaan } \\
\text { atas kinerja yang baik }\end{array}$ & Skala Likert \\
\hline $\begin{array}{l}\text { Prestasi } \\
\left(\mathrm{X}_{7}\right)\end{array}$ & $\begin{array}{l}\text { Penghargaan terhadap } \\
\text { karyawan yang } \\
\text { berprestasi, baik aspek } \\
\text { kemampuan individu, tim, } \\
\text { manajerial atau yang } \\
\text { lainya }\end{array}$ & $\begin{array}{l}\text { 1. Tunjangan khusus sesuai } \\
\text { dengan prestasi } \\
\text { 2. Mendapatkan beasiswa } \\
\text { pendidikan } \\
\text { 3. Mendapatkan promosi } \\
\text { jabatan }\end{array}$ & Skala Likert \\
\hline
\end{tabular}

\section{HASIL PENELITIAN}

Huda Group adalah gabungan atau konsorsium dari beberapa lembaga yang bergerak di bidang dakwah, pendidikan dan sosial. Lembagalembaga tersebut adalah sebagai berikut. 
Yayasan Cinta Remaja Bangsa (CRB) yang bergerak di bidang pembinaan para pelajar dan remaja, memberikan mereka penyuluhan dengan mengadakan seminar-seminar, pelatihan-pelatihan, dan memberikan mereka bacaan-bacaan yang berguna untuk pembinaan jati diri dan akhlak mereka secara cuma-cuma.

Yayasan Takrimul Qur'an (YATAQU) yang bergerak dalam penyebaran al-Qur'an ke pondok-pondok pesantren khususnya dan masjidmasjid pada umumnya. Lebih dari 500 pesantren dan masjid di Jawa Barat telah mendapatkan bantuan al-Qur'an melalui YATAQU. Dalam jangka waktu yang tidak lama lagi YATAQU akan mempunyai pesantren Tahfizul Qur'an dan Bahasa Arab untuk mencetak guru-guru Al-Qur'an dan Bahasa Arab.

Yayasan Mutiara Surga (YAMUSA) yang bergerak dalam pemberian bantuan pangan untuk kaum dhuafa dan fakir miskin. Lebih dari 5000 paket bantuan telah diberikan kepada kaum dhuafa dan fakir miskin di Wilayah Jawa Barat.

Yayasan Nurul Ummah Nusantara (NUN) yang bergerak di bidang dakwah secara umum termasuk tabligh akbar, pengajian-pengajian umum, penyebaran buku-buku Islam, dan lain-lain. Lebih dari 1 juta buku, kartu dakwah dan literatur telah disebarkan kepada kaum muslimin di berbagai daerah di Indonesia.

Yayasan Huda Cendekia (YHC) yang bergerak dalam pemberian beasiswa pendidikan kepada putra-putra bangsa terbaik dari seluruh Indonesia. Beasiswa diberikan penuh yang mencakup biaya pendidikan, asrama, makan dan sarana belajar lainnya. Huda Group memiliki visi yaitu "Menjadi Lembaga Nirlaba yang Visioner dan amanah dalam bidang pendidikan, dakwah, dan sosial pada tahun 2020".

\section{Pengujian Validitas dan Reliabilitas}

Pengujian validitas dan reliabilitas instrument dilakukan dengan mencoba daftar pernyataan yang telah ditanyakan pada responden terhadap responden yang lainnya di luar sampel yang telah ditentukan, dalam penelitian ini dilakukan kepada karyawan Lembaga Huda Grup sebanyak 31 orang. 


\section{Uji Validitas Instrumen}

Instrumen yang valid mempunyai arti bahwa alat ukur yang digunakan dalam bentuk pernyataan untuk memperoleh data (mengukur) juga dinyatakan valid.Item yang memiliki korelasi positif tinggi pula. Masrun dan Sugiyono (2006) menuliskan dalam bukunya bahwa suatu instrument valid apabila nilai $r>0,3$.

\section{Uji Validitas instrument Tauhid dan Jihad}

Pada Tabel 2 dapat dilihat $r$ hitung untuk setiap butir pernyataan yangdilakukan untuk pengukur tauhid dan jihad responden. Nilai $r$ hitung keseluruhannya $>$ 0,3 yang berarti bahwa butir pernyataan faktor tauhid dan jihad adalah valid.

\section{Tabel 2}

Uji Validitas Tauhid dan Jihad

\begin{tabular}{|c|l|c|l|}
\hline NO & \multicolumn{1}{|c|}{ PERNYATAAN } & r hitung & Ket \\
\hline 1 & $\begin{array}{l}\text { Sebelum bekerja diawali dengan membaca } \\
\text { bismillah }\end{array}$ & 0,481 & Valid \\
\hline 2 & $\begin{array}{l}\text { Setelah bekerja diakhiri dengan membaca } \\
\text { Alhamdulillah dan tawakkal }\end{array}$ & 0,402 & Valid \\
\hline 3 & $\begin{array}{l}\text { Bersyukur kepada Allah SWT bisa bekerja } \\
\text { di lembaga ini }\end{array}$ & 0,427 & Valid \\
\hline 4 & $\begin{array}{l}\text { Jika datang waktu shalat, aktivitas berhenti } \\
\text { dan melakukan shalat berjamaah }\end{array}$ & 0,574 & Valid \\
\hline 5 & $\begin{array}{l}\text { Bekerja pada lembaga ini membuat saya } \\
\text { berguna di dalam kehidupan masyarakat }\end{array}$ & 0,371 & Valid \\
\hline 6 & $\begin{array}{l}\text { Saya bekerja dengan semangat ibadah dan } \\
\text { jihad }\end{array}$ & 0,465 & Valid \\
\hline
\end{tabular}

Sumber : Hasil Penelitian, 2016 (Data Olah)

\section{Uji Validitas Kepemimpinan}

Pada Tabel 4.5 dapat dilihat $r$ hitung untuk setiap butir pernyataan yangdilakukan untuk pengukur kepemimpinan responden. Nilai $r$ hitung keseluruhannya > 0,3 yang berarti bahwa butir pernyataan kepemimpinan adalah valid. 
Tabel 3

Uji Validitas Kepemimpinan

\begin{tabular}{|c|l|c|l|}
\hline NO & \multicolumn{1}{|c|}{ PERNYATAAN } & r hitung & Ket \\
\hline 1 & $\begin{array}{l}\text { Pemimpin memberi keputusan dengan cara } \\
\text { bermusyawarah }\end{array}$ & 0,528 & Valid \\
\hline 2 & $\begin{array}{l}\text { Pemimpin selalu memberi perhatian kepada } \\
\text { karyawan }\end{array}$ & 0,559 & Valid \\
\hline 3 & $\begin{array}{l}\text { Dalam menyelesaikan masalah pemimpin } \\
\text { selalu bertindak bijaksana }\end{array}$ & 0,464 & Valid \\
\hline 4 & $\begin{array}{l}\text { Pimpinan menghargai gagasan yang } \\
\text { disampaikan bawahan }\end{array}$ & 0,698 & Valid \\
\hline 5 & $\begin{array}{l}\text { Pimpinan tidak peduli dengan masalah } \\
\text { bawahan }\end{array}$ & 0,363 & Valid \\
\hline
\end{tabular}

Sumber : Hasil Penelitian, 2016 (Data Olah)

\section{Uji Validitas Komunikasi}

Pada Tabel 4.6 dapat dilihat $r$ hitung untuk setiap butir pernyataan yangdilakukan untuk pengukur komunikasi responden. Nilai $r$ hitung keseluruhannya $>0,3$ yang berarti bahwa butir pernyataan komunikasi adalah valid.

Tabel 4

Uji Validitas Komunikasi

\begin{tabular}{|c|l|c|c|}
\hline NO & \multicolumn{1}{|c|}{ PERNYATAAN } & r hitung & Ket \\
\hline 1 & $\begin{array}{l}\text { Mudah untuk berkomunikasi dengan } \\
\text { pimpinan }\end{array}$ & 0,390 & Valid \\
\hline 2 & $\begin{array}{l}\text { Dalam melaksanakan tugas, perintah } \\
\text { jelas tidak mengalami hambatan } \\
\text { komunikasi }\end{array}$ & 0,466 & Valid \\
\hline 3 & $\begin{array}{l}\text { Hubungan antara atasan dan bawahan } \\
\text { baik, tidak kaku } \\
\text { Ketika bertemu saling mengucapkan } \\
\text { salam }\end{array}$ & 0,401 & Valid \\
\hline 4 & 0,405 & Valid \\
\hline
\end{tabular}

Sumber : Hasil Penelitian, 2016. 


\section{Uji Validitas Kebutuhan}

Pada Tabel 5 dapat dilihat $r$ hitung untuk setiap butir pernyataan yangdilakukan untuk pengukur kebutuhan responden. Nilai $r$ hitung keseluruhannya > 0,3 yang berarti bahwa butir pernyataan kebutuhan adalah valid.

Tabel 5

Uji Validitas Kebutuhan

\begin{tabular}{|c|l|c|c|}
\hline NO & \multicolumn{1}{|c|}{ PERNYATAAN } & r hitung & Ket \\
\hline 1 & $\begin{array}{l}\text { Saya berniat untuk bekerja di } \\
\text { lembaga ini selamanya }\end{array}$ & 0,556 & Valid \\
\hline 2 & $\begin{array}{l}\text { Tugas dan tanggung jawab sesuai } \\
\text { dengan tingkat pendidikan dan atau } \\
\text { kemampuan }\end{array}$ & 0,429 & Valid \\
\hline 3 & $\begin{array}{l}\text { Suasana kerja yang Islami } \\
\text { memenuhi kebutuhan ruhani }\end{array}$ & 0,542 & Valid \\
\hline 4 & $\begin{array}{l}\text { Tersedia perlengkapan untuk } \\
\text { keselamatan kerja }\end{array}$ & 0,659 & Valid \\
\hline 5 & $\begin{array}{l}\text { Karyawan telah menjadi anggota } \\
\text { asuransi syariah }\end{array}$ & 0,437 & Valid \\
\hline
\end{tabular}

Sumber : Hasil Penelitian, 2016 (Data Olah)

\section{Uji Validitas Pelatihan}

Pada Tabel 6 dapat dilihat $r$ hitung untuk setiap butir pernyataan yang dilakukan untuk pengukur pelatihan responden. Nilai $r$ hitung keseluruhannya $>0,3$ yang berarti bahwa butir pernyataan pelatihan adalah valid.

Tabel 6

Uji Validitas Pelatihan

\begin{tabular}{|c|l|c|c|}
\hline NO & \multicolumn{1}{|c|}{ PERNYATAAN } & r hitung & Ket \\
\hline 1 & $\begin{array}{l}\text { Bekerja di lembaga ini, karyawan } \\
\text { berkembang kemampuanya }\end{array}$ & 0,446 & Valid \\
\hline 2 & $\begin{array}{l}\text { Ada pelatihan-pelatihan untuk } \\
\text { meningkatkan kemampuan }\end{array}$ & 0,828 & Valid \\
\hline 3 & $\begin{array}{l}\text { Anggaran pelatihan difasilitasi } \\
\text { oleh yayasan }\end{array}$ & 0,611 & Valid \\
\hline 4 & $\begin{array}{l}\text { waktu pelatihan terjadwal untuk } \\
\text { karyawan }\end{array}$ & 0,484 & Valid \\
\hline
\end{tabular}

Sumber : Hasil Penelitian, 2016. 


\section{Uji Validitas Kompensasi}

Pada Tabel 7 dapat dilihat $r$ hitung untuk setiap butir pernyataan yang dilakukan untuk pengukur kompensasi responden. Nilai $r$ hitung keseluruhannya $>0,3$ yang berarti bahwa butir pernyataan kompensasi adalah valid.

Tabel 7

Uji Validitas Kompensasi

\begin{tabular}{|c|l|c|c|}
\hline NO & \multicolumn{1}{|c|}{ PERNYATAAN } & r hitung & Ket \\
\hline 1 & Gaji selalau dibayarkan tepat waktu & 0,504 & Valid \\
\hline 2 & $\begin{array}{l}\text { Besarnya gaji yang diperoleh } \\
\text { sesuai dengan bobot dan tanggung } \\
\text { jawab pekerjaan }\end{array}$ & 0,601 & Valid \\
\hline 3 & $\begin{array}{l}\text { Yayasan memberikan fasilitas } \\
\text { inventaris untuk bekerja }\end{array}$ & 0,619 & Valid \\
\hline 4 & $\begin{array}{l}\text { Karyawan mendapatkan tunjangan } \\
\text { hari raya }\end{array}$ & 0,723 & Valid \\
\hline
\end{tabular}

Sumber : Hasil Penelitian, 2016.

\section{Uji Validitas Prestasi}

Pada Tabel 8 dapat dilihat $r$ hitung untuk setiap butir pernyataan yang dilakukan untuk pengukur prestasi responden. Nilai $r$ hitung keseluruhannya $>0,3$ yang berarti bahwa butir pernyataan prestasi adalah valid.

Tabel 8

Uji Validitas Prestasi

\begin{tabular}{|c|l|c|c|}
\hline NO & \multicolumn{1}{|c|}{ PERNYATAAN } & r hitung & Ket \\
\hline 1 & $\begin{array}{l}\text { Pemberian penghargaan buat } \\
\text { karyawan yang berprestasi akan } \\
\text { memotivasi kerja karyawan }\end{array}$ & 0,790 & Valid \\
\hline 2 & $\begin{array}{l}\text { Standar prestasi di lembaga ini } \\
\text { jelas }\end{array}$ & 0,563 & Valid \\
\hline 3 & $\begin{array}{l}\text { Prestasi di nilai berdasarkan } \\
\text { hasil kerja karyawan }\end{array}$ & 0,478 & Valid \\
\hline 4 & $\begin{array}{l}\text { Karyawan berprestasi } \\
\text { mendapatkan beasiswa } \\
\text { pendidikan, atau promosi } \\
\text { jabatan atau dinaikan gajinya }\end{array}$ & 0,576 & Valid \\
\hline
\end{tabular}

Sumber : Hasil Penelitian, 2017. 


\section{Uji Reliabilitas Instrumen}

Uji reliabilitas digunakan untuk mengetahui jawab yang diberikan untuk pernyataan yang diulang adalah sama. Uji ini digunakan untuk melihat konsistensi jawaban. Pengujian reliabilitas (tingkat kehandalan) dari suatu variabel dapat dilakukan dengan melihat nilai Cronbach Alpha, Ghozali (2002) menuliskan dalam bukunya bahwa suatu instrument dikatakan handal apabila nilai Cronbach Alpha $>0,60$.

Pada Tabel 9 Dapat dilihat nilai Cronbach Alpha untuk setiap variabel yang digunakan nilainya $>0,6$ yang menandakan bahwa setiap butir variable adalah handal (reliable).

Tabel 9

Uji Reliabilitas Instrumen

\begin{tabular}{|c|r|r|r|r|}
\hline \multicolumn{5}{|c|}{ Item-Total Statistics } \\
\hline Variabel & $\begin{array}{c}\text { Scale Mean } \\
\text { if Item } \\
\text { Deleted } \\
\text { Variance if } \\
\text { Item } \\
\text { Deleted }\end{array}$ & $\begin{array}{r}\text { Scale } \\
\text { Item-Total } \\
\text { Correlation }\end{array}$ & $\begin{array}{r}\text { Alpha if Item } \\
\text { Deleted }\end{array}$ \\
\hline Tauhid_jihad & 104.7000 & 135.630 & .545 & .771 \\
\hline Kepemimpina & 111.5500 & 106.403 & .755 & .708 \\
\hline Komunikasi & 116.6125 & 136.367 & .515 & .773 \\
\hline Kebutuhan & 116.7625 & 150.335 & -.027 & .815 \\
\hline Pelatihan & 115.8750 & 72.516 & .630 & .790 \\
\hline Kompensasi & 117.1250 & 109.630 & .751 & .714 \\
\hline Prestasi & 117.9250 & 93.868 & .803 & .685 \\
\hline
\end{tabular}

Sumber : Hasil Penelitian, 2016. 


\section{Hasil Analisis Interdependen Variabel}

Hasil pengujian analisis faktor dengan variabel interdependen dengan menggunakan SPSS.

Hasil Correlation Matrix

\section{Tabel 10}

\section{Correlation Matrix}

\begin{tabular}{|cc|r|r|r|r|r|r|r|}
\hline & $\begin{array}{c}\text { Tauhid_ } \\
\text { jihad }\end{array}$ & $\begin{array}{c}\text { Kepemim } \\
\text { pinan }\end{array}$ & $\begin{array}{c}\text { Komunik } \\
\text { asi }\end{array}$ & $\begin{array}{c}\text { Kebutu- } \\
\text { han }\end{array}$ & $\begin{array}{c}\text { Pelatiha } \\
\text { n }\end{array}$ & $\begin{array}{r}\text { Kompensa } \\
\text { si }\end{array}$ & $\begin{array}{c}\text { Prest } \\
\text { asi }\end{array}$ \\
\hline Correlation & Tauhidjihad & 1.000 & .558 & .427 & .322 & .324 & .399 & .511 \\
& Kepemimpinan & .558 & 1.000 & .556 & .145 & .514 & .580 & .804 \\
& Komunikasi & .427 & .556 & 1.000 & .455 & .378 & .319 & .320 \\
& Kebutuhan & .322 & .145 & .455 & 1.000 & -.160 & -.148 & -.137 \\
& Pelatihan & .324 & .514 & .378 & -.160 & 1.000 & .672 & .639 \\
& Kompensasi & .399 & .580 & .319 & -.148 & .672 & 1.000 & .799 \\
& Prestasi & .511 & .804 & .320 & -.137 & .639 & .799 & 1.000 \\
\hline Sig. (1-tailed) & Tauhid_jihad & & .000 & .000 & .002 & .002 & .000 & .000 \\
& Kepemimpinan & .000 & & .000 & .099 & .000 & .000 & .000 \\
& Komunikasi & .000 & .000 & & .000 & .000 & .002 & .002 \\
& Kebutuhan & .002 & .099 & .000 & & .078 & .094 & .113 \\
& Pelatihan & .002 & .000 & .000 & .078 & & .000 & .000 \\
& Kompensasi & .000 & .000 & .002 & .094 & .000 & & .000 \\
& Prestasi & .000 & .000 & .002 & .113 & .000 & .000 & \\
\hline
\end{tabular}

Pada Table 4.19 menjelaskan hubungan antara variable di antaranya Kepemimpinan (X2) dan Prestasi (X7) adalah 0.804 (sangat kuat) demikian juga konpensasi (X6) dengan prestasi (X7) cukup kuat hubunganya dengan nilai 0.799. Sedangkan hubungan yang paling lemah adalah antara variabel Kebutuhan (X4) dengan Pelatihan (X5) dengan nilai -0,160.

\section{Hasil KMO and Bartlett's test}

Tabel 11.

$21 \mathrm{KMO}$ and Bartlett's test

KMO and Bartlett's Test

\begin{tabular}{ccr}
\hline \multicolumn{3}{c}{ Kaiser-Meyer-Olkin Measure of Sampling } \\
Adequacy. & .730 \\
Bartlett's Test of & Approx. Chi-Square & 327.150 \\
Sphericity & Df & 21 \\
\cline { 2 - 3 } & Sig. & .000 \\
\hline
\end{tabular}

Pada Tabel $11 \mathrm{KMO}$ and Bartlett's test, terlihat angka K-M-O Measure of Sampling Adequacy (MSA) adalah 0,730. Oleh karena angka MSA di atas 
0,5, maka kumpulan variabel tersebut dapat diproses lebih lanjut. Selanjutnya tiap variabel dianalisis untuk mengetahui mana yang dapat diproses lebih lanjut dan mana yang harus dikeluarkan. Kesimpulan yang sama dapat dilihat pula pada angka KMO and Bartlett's test (yang ditampakkan dengan angka Chi-Square) sebesar 327,150 dengan signifikansi 0,000.

\section{Hasil Communalities}

Tabel 12

Communalitie

\begin{tabular}{|c|r|r|}
\hline Variabel & \multicolumn{1}{|c|}{ Initial } & \multicolumn{2}{|c|}{ Extraction } \\
\hline Tauhid_jihad & 1.000 & .594 \\
\hline Kepemimpinan & 1.000 & .771 \\
\hline Komunikasi & 1.000 & .686 \\
\hline Kebutuhan & 1.000 & .846 \\
\hline Pelatihan & 1.000 & .669 \\
\hline Kompensasi & 1.000 & .788 \\
\hline Prestasi & 1.000 & .873 \\
\hline Extraction Method: Principal Component Analysis. \\
\hline
\end{tabular}

Pada tabel Communalities variabel 7 (Prestasi), angka 0,873 berarti $87,3 \%$ sangat erat dalam membentuk faktor motivasi, demikian dengan variabel-variabel yang lainnya. Semua variabel dapat dijelaskan oleh faktor yang terbentuk dengan ketentuan semakin besar communalities, maka semakin erat hubungan variabel yang bersangkutan dengan motivasi yang terbentuk.

\section{Hasil Variance Explained}

Tabel 13

Total Variance Explained

\begin{tabular}{|c|c|c|c|c|c|c|}
\hline \multirow{2}{*}{ Component } & \multicolumn{3}{|c|}{ Initial Eigenvalues } & \multicolumn{3}{c|}{ Extraction Sums of Squared } \\
& \multicolumn{3}{|c|}{ Loadings } \\
\cline { 2 - 7 } & Total & $\begin{array}{c}\text { \% of } \\
\text { Variance }\end{array}$ & $\begin{array}{c}\text { Cumulative } \\
\%\end{array}$ & Total & $\begin{array}{c}\text { \% of } \\
\text { Variance }\end{array}$ & $\begin{array}{c}\text { Cumulativ } \\
\text { e \% }\end{array}$ \\
\hline 1 & 3.660 & 52.290 & 52.290 & 3.660 & 52.290 & 52.290 \\
\hline
\end{tabular}




\begin{tabular}{|r|r|r|r|r|r|r|}
\hline 2 & 1.566 & 22.377 & 74.666 & 1.566 & 22.377 & 74.666 \\
\hline 3 & .628 & 8.977 & 83.644 & & & \\
\hline 4 & .432 & 6.169 & 89.813 & & & \\
\hline 5 & .349 & 4.984 & 94.796 & & & \\
\hline 6 & .274 & 3.921 & 98.717 & & & \\
\hline 7 & .090 & 1.283 & 100.000 & & & \\
\hline
\end{tabular}

Extraction Method: Principal Component Analysis.

Pada Tabel Total Variance Explained, variabel yang dianalisis ternyata dapat dikelompokkan menjadi 2 faktor, yaitu eigenvalues yang menunjukkan angka lebih besar dari satu. Dengan demikian ada 2 faktor yang terbentuk. Penentuan variabel yang masuk faktor dilakukan dengan memperbandingkan besaran korelasi pada setiap baris. Angka korelasi di bawah 0,5 menunjukkan indikasi korelasi yang lemah sedangkan di atas 0,5 berindikasi kuat korelasinya.

Hasil Component Matrix ${ }^{a}$

Tabel 14.

Component Matrix ${ }^{\mathrm{a}}$

\begin{tabular}{|c|c|c|}
\hline \multirow{2}{*}{ Variabel } & \multicolumn{2}{|c|}{ Component } \\
\cline { 2 - 3 } & 1 & 2 \\
\hline Prestasi & .892 & -.278 \\
\hline Kepemimpinan & .873 & .100 \\
\hline Kompensasi & .820 & -.340 \\
\hline Pelatihan & .755 & -.314 \\
\hline Tauhid_jihad & .681 & .361 \\
\hline Komunikasi & .622 & .547 \\
\hline Kebutuhan & .099 & .914 \\
\hline
\end{tabular}

Extraction Method: Principal Component

Analysis.

Tabel Component Matrix Pada tabel Component Matrix menunjukkan distribusi ketujuh variabel tersebut pada dua factor yang ada. Sedangkan angka yang ada pada tabel tersebut adalah faktor loadings, atau besar Jurnal Manajemen Pendidikan Islam, Volume.I, Nomor.1, Januari 2018 
korelasi antara suatu variabel dengan faktor1atau faktor 2. Seperti pada variabel prestasi, korelasi antara variabel prestasi dengan faktor 1 adalah 0,892 (sangat kuat), sedang korelasi variabel Prestasi dengan faktor 2 adalah $-0,278$ (lemah). Dengan demikian dapat dikatakan variabel prestasi dapat dimasukkan sebagai komponen faktor 1 .

Pada variabel kepemimpinan, korelasi antara variabel kepemimpinan dengan factor 1 adalah 0,873 (cukupkuat), sedang korelasi variabel kepemimpinan dengan faktor 2 adalah 0,100 (lemah). Dengan demikian dapat dikatakan variabel kepemimpinan dapat dimasukkan sebagai komponen faktor 1. Pada variabel kompensasi, korelasi antara variabel kompensasi dengan faktor 1 adalah 0,820 (cukup kuat), sedang korelasi variabel kemasan dengan faktor 2 adalah - 0,340.Dengan demikian dapat dikatakan variabel Kompensasi dapat dimasukkan sebagai komponen faktor 1. Pada variabel Tauhid dan Jihad, korelasi antara variabel tauhid dan jihad dengan faktor 1 adalah 0,681 (cukupkuat), sedang korelasi variabel harga dengan faktor 2 adalah 0,361 (lemah). Dengan demikian dapat dikatakan variabel tauhid dan jihad dapatdimasukkan sebagai komponen faKtor 1 . Pada variabel komunikasi, korelasi antara variabel komunikasi dengan faktor 1 adalah 0,622 (cukup kuat), sedang korelasi variabel komunikasi dengan faktor 2 adalah 0,547 (lemah). Dengan demikian dapat dikatakan variabel komunikasi dapat dimasukkan sebagai komponen faktor 1. Pada variabel kebutuhan, korelasi antara variabel kebutuhan dengan faktor 1 adalah 0,099 (lemah), sedang korelasi variabela kebutuhan dengan faktor 2 adalah 0,914 (sangat kuat). Dengan demikian dapat dikatakan variabel kebutuhan dapat dimasukkan sebagai komponen faktor 2.

\section{SIMPULAN}

Bahwa faktor motivasi pada Karyawan Lembaga Huda Group adalah tauhid dan jihad, kepemimpinan, komunikasi, kebutuhan, pelatihan, kompensasi, dan prestasi secara bersama-sama memiliki korelasi yang kuat terhadap motivasi.

Berdasarkan hasil penelitian dan pembahasan pada bab sebelumnya, maka ditarik kesimpulan sebagai berikut; 1) Faktor tauhid dan jihad mencapai nilai 0,594 atau 59,4 \% memiliki hubungan yang kuat terhadap 
motivasi pada karyawan Lembaga Huda Group di Tamansari Bogor, namun lebih rendah dibandingkan dengan variabel lainnya, 2) Faktor kepemimpinan mencapai nilai 0,771 atau 77,1\% memiliki hubungan sangat kuat terhadap motivasi pada karyawan pada lembaga Huda Group di Tamansari Bogor, 3) Faktor komunikasi mencapai nilai 0,686 atau $68,6,1 \%$ memiliki hubungan yang kuat terhadap nmotivasi pada karyawan pada lembaga Huda Group di Tamansari Bogor, 4) Faktor kebutuhan mencapai nilai 0,846 atau 84,6\% menunjukkan bahwa hubungan sangat kuat terhadap motivasi pada karyawan pada lembaga Huda Group di Tamansari Bogor, 5) Faktor pelatihan mencapai nilai 0,669 atau $66,9 \%$ menunjukkan bahwa hubungan kuat terhadap motivasi pada karyawan pada lembaga Huda Group di Tamansari Bogor, 6) Faktor kompensasi mencapai nilai 0,788 atau $78,8 \%$ menunjukkan bahwa hubungan sangat kuat terhadap motivasi pada karyawan pada lembaga Huda Group di Tamansari Bogor, 7) Faktor kompensasi mencapai nilai 0,788 atau $78,8 \%$ menunjukan bahwa hubungan sangat kuat terhadap motivasi pada karyawan pada lembaga Huda Group di Tamansari Bogor, dan 8) Faktor prestasi mencapai nilai yang paling tinggi dibandingkan varibel lain sebesar 0,873 atau $87,3 \%$ menunjukan bahwa hubungan sangat kuat terhadap motivasi pada karyawan pada lembaga Huda Group di Tamansari Bogor.

\section{DAFTAR PUSTAKA}

Abdullah, M. Ma'ruf. (2012) Manajemen Berbasis Syariah. Yogyakarta: Aswaja Presindo

Arep, Ishak dan Hendri Tanjung. (2004). Manajemen Motivasi. Jakarta. PT. Grasindo.

Arikunto, Suharsimi. (2006) Prosedur Penelitian Suatu Pendekatan Praktik. Yogyakarta:Rineka Cipta.

Ash-Shiddieqy, Hasbi. (2012) Pedoman Zakat, Jakarta :Pustaka Rizki Putra.

Fahmi, dkk. (2014 ) HRD Syariah Teori dan Implementasi, Jakarta. PT. Gramedia.

Hafidhuddin, Didin. (2002 ) Zakat Dalam Perekonomian modern, Jakarta : PT Gema Insani Press.

Hamka (1999) Tafsir Al-Azhar Jakarta : Al Azhar Press. 
Hasibuan, Malayu S.P (2005) Manajemen Sumber daya Manusia, Jakarta:PT Bumi Aksara.

Hidayat, A.Aziz Alimul (2007) Metode Penelitian Keperawatan dan Teknik Analisis Data, Jakarta: Salemba Medika.

Kartono. (2010) Pemimpin dan Kepemimpinan, Jakarta: Rajawali Pers.

Marimin, Prof. Dr. Ir., Tanjung, Hendri, Ph.D, Prabowo, Haryo, M.M. (2006). Sistem Informasi Manajemen Sumber Daya Manusia. Jakarta : PT. Grasindo.

Masyhudzulhak. (2012) Manajemen Sumber Daya Manusia, LP2S Lembaga Pengkajian dan Pengembangan Sumber Daya.

Masyhudzulhak. (2013) Manajemen Stategi, LP2S Lembaga Pengkajian dan Pengembangan Sumber Daya.

Minto Waluyo (2012) Teknik Analisis Data Multivariat Dengan Structural Equation Modelling ( SEM ). Jatim : UPN Veteran.

Mu'inan Rafi'. (2011) Subjek : Zakat; Pengolahan Zakat, Jakarta : Mitra Setia. Ridwan, Drs., M.B.A (2009) Metode Dan Teknik Menyusun Proposal Penelitian. Bandung: Alfabeta.

Sugiyono, Prof. Dr. (2004) Metode Penelitian Kuantitati dan R\&D. Bandung : Alfabeta.

Tasmara, Toto. (2002). Etos Kerja Pribadi Muslim. Yogyakarta. PT Dana Bhakti Wakaf.

Jurnal:

Eddy M. Sutanto dan Anastasia Tania (2013) AGORA Vol. 1, No.3, (2013) Pengaruh Motivasi Kerja dan Kepuasan Kerja terhadap Komitmen Organisasional Karyawan PT. Dai knife di Surabaya

Bakhri, Boy. (2015) Jurnal Economica, Vol. I No. 1 Januari 2015. Kesiapan

Enggar Dwi Jatmiko, Bambang Swasto, Gunawan Eko N, Jurnal Administrasi Bisnis (JAB) Vol. 21 No. 1 April 2015 Pengaruh Motivasi Kerja Dan Komitmen Organisasional Terhadap Kinerja Karyawan (Studi Pada Karyawan Kompartemen Pabrik II PT. Petrokimia Gresik)

Fadli, M. (2014). Jurnal Optimalisasi Kebijakan Ketenagakerjaan Dalam Menghadapi MEA 2015 
Firdaus, Ahmad. (2013). Penerapan "Acceleration To Improve The Quality Of Human Resources"

Hanantijo, Djoko. Jurnal Strategi SDM Dalam Menghadapi Persaingan Global.

Indonesia Menghadapi Masyarakat Ekonomi Asean 2015 Dari Perspektif Daya Saing Nasional.

La ode Makta (2013) Pengaruh Motivasi Kerja dengan Kinerja Perawat Pelaksana di Unit Rawat Inap RS. Stella Maris Makassar Tahun 2013. Langkah Dalam Mengoptimalkan Daya Saing Indonesia Di MEA 2015.

Ni Made Nurcahyani, I.G.A.Dewi Adnyani (2016), E-Jurnal Manajemen Unud, Vol. 5, No.1, 2016:500-532 Pengaruh Kompensasi Dan Motivasi Terhadap Kinerja Karyawan Dengan Kepuasan Kerja Sebagai Variabel Intervening.

Priyatna, M. (2014). Konsep pendidikan jiwa (nafs) Menurut al qur'an dan hadits.Jurnal Edukasi Islam, 3 (05), 520-532.

Priyatna, M. (2015). Implementasi manajemen pendidikan berbasis syariah di STAI Al-Hidayah Bogor. Jurnal Edukasi Islam, 4 (07), 787-805.

Priyatna, M. (2016). Manajemen pengembangan sdm pada lembaga pendidikan Islam. Jurnal Edukasi Islam, 5 (09), 1231-1250.

Priyatna, M. (2016). Pendidikan karakter berbasis kearifan lokal. Jurnal Edukasi Islam, 5 (10), 1311-1336.

Priyatna, M. (2017). Manajemen pembelajaran program kulliyatul mualimin al-Islamiyah (KMI) di pondok pesantren modern al-ihsan baleendah bandung. Jurnal Edukasi Islam, 6 (11), 17-38.

Sindi Larasati (2014) Jurnal Vol No. 3 Desember 2014 Pengaruh Motivasi Kerja terhadap Kinerja Karyawan Wilayah Telkom Jabar Barat Utara (Witel Bekasi).

Wuryandani, Dewi (2014). Peluang Dan Tantangan Sdm Indonesia Menyongsong Era Masyarakat Ekonomi Asean.

\section{Tesis}

Agustina (2012) Faktor-faktor Motivasi yang Mempengaruhi Kinerja Karyawan pada PT Gaya Manunggal Kresitama 
Ardhyan Krisdiyanto (2010) Analisis Faktor-Faktor Yang Mempengaruhi Motivasi Dan Pengaruhnya Terhadap Peningkatan Kinerja Karyawan.

Farida (2009) Analisis Faktor-Faktor Yang Berpengaruh Terhadap Motivasi Kerja Petugas Pelaksana Manajemen Terpadu Balita Sakit (MTBS) Di Puskesmas Kota Surabaya.

Ilham Nur (2007) Penelitian pada Sistem Penggajian Karyawan Di PT Petrokimia Gresik.

Raika (2009) Analisis Faktor-Faktor Motivasi Kerja Penyuluh Perindustrian pada Kantor Dinas Perindustrian dan Perdagangan Kota Medan.

Ramadhian tahun (2006) Analisis faktor-faktor dari motivasi yang meliputi karakteristik individu,karakteristik pekerjaan, dan karakteristik situasi kerja terhadap produktivitas kerjakaryawan di PT. Radio Karya Pancaran Swara Media Boyolali. 